\title{
DINAMIKA PSIKOLOGIS ANAK DENGAN TARAF INTELEKTUAL BORDERLINE YANG MENGALAMI KECEMASAN DI SEKOLAH
}

\section{DYNAMICS OF PSYCHOLOGICAL CHILDREN WITH INTELLECTUAL DEGREE BORDERLINE WHO SUSTAINING ON ANXIETY AT SCHOOL}

\author{
Angelina Dyah Arum Setyaningtyas \\ Universitas Mercubuana Yogyakarta \\ angelina@mercubuana-yogya.ac.id
}

\begin{abstract}
Abstrak
Tujuan penelitian ini yakni mengetahui dinamika psikologis anak dengan taraf intelektual borderline yang mengalami kecemasan di sekolah. Penelitian ini merupakan penelitian psikologi yang pengambilan datanya dengan menggunakan metode kualitatif. Subjek penelitian sebanyak 2 orang, dimana anak tersebut dipilih berdasarkan kriteria anak-anak usia 6-12 tahun, memiliki IQ Borderline yang dibuktikan dengan hasil test IQ, dan menunjukan tingkat kecemasan yang tinggi dengan pada skala Children Test Anxiety Scale (CTAS). Hasil menunjukkan bahwa kecemasan akademik yang berlebihan yang dialami oleh anak dengan intelektual borderline merupakan hasil dinamika dari kapasitas intelektual yang kurang dan kerentanan kepribadian yang juga menjadi akibat dari kapasitas intelektual yang terbatas. Di sekolah, subjek mendapatkan tekanan beban tugas yang padat, juga tuntutan lingkungan mengenai prestasi, hal ini merupakan situasi yang menekan bagi subjek, yang kemudian diproses secara kognitif oleh subjek menggunakan pengalaman dan nilai yang dimiliki anak. Karena problem solving yang dimiliki anak terbatas, maka mekanisme pertahanan diri dari kecemannya pun menjadi tidak efektif untuk mereduksi kecemasannya, sehingga kecemasannya semakin kuat.
\end{abstract}

Kata Kunci: anak, taraf intelektual borderline, kecemasan di sekolah

\begin{abstract}
The purpose of this study is to know the psychological dynamics of children with borderline intellectual level who experience anxiety in school. This research is a psychological research that takes data using qualitative methods. The research subjects were 2 people, where the child was selected based on the criteria of children aged 6-12 years, had an IQ Borderline as evidenced by the IQ test results, and showed a high level of anxiety on the scale of the Children Test Anxiety Scale (CTAS). The results show that excessive academic anxiety experienced by children with borderline intellectuals is a result of the dynamics of lack of intellectual capacity and personality vulnerability which is also a result of limited intellectual capacity. In school, the subject gets a heavy duty burden, also the demands of the environment regarding achievement, this is a situation that presses on the subject, which is then processed cognitively by the subject using the experiences and values of the child. Because problem solving possessed by children is limited, then the self-defense mechanism from his brilliance becomes ineffective in reducing his anxiety, so that his anxiety gets stronger.
\end{abstract}

Keywords: children, borderline intellectual level, anxiety in school

\section{PENDAHULUAN}

Kecemasan tidak hanya dapat dialami oleh orang dewasa, tetapi juga dapat dirasakan pula oleh anak ataupun remaja yang masih duduk di bangku sekolah. Ada beberapa penelitian yang memberikan gambaran prevalensi terjadinya kecemasan pada usia anak, antara lain Gosch, Schroder, Mauro, \& Compton (2006) dalam penelitiannya menemukan bahwa prevalensi gangguan kecemasan pada anak berkisar 12\% sampai 20\%. Angka lain disampaikan dari penelitian Wenar \& 
Kerig (2005) yang menemukan 10,7\% sampai 17,3\% terjadi gangguan kecemasan pada anak dan remaja. Selain itu, Last dan Strauss (dalam Grahita, 2011) juga menyatakan bahwa 43,4\% kasus penolakan sekolah juga dilatarbelakangi dari kecemasan. Last dan Strauss (dalam Grahita, 2011) juga melaporkan penelitian lain yang menunjukkan dari 100 anak 21 diantaranya mengalami kecemasan.

Menurut Bogels \& Zigerman (dalam Nevid, 2005) dalam studinya, anak dan remaja yang sangat cemas menunjukkan bias kognitif dalam mengolah informasi, seperti menginterpretasikan situasi-situasi yang ambigu sebagai ancaman, mengharapkan hasil yang negatif, meragukan kemampuan mereka dalam berhadapan dengan situasi bermasalah, melakukan self-talk yang negatif. Hal tersebut digabung dengan self-confidence yang rendah, mendorong penolakan terhadap aktivitas-aktivitas yang ditakuti dengan teman-teman, di sekolah dan di mana pun.

Menurut Akins \& Craske (dalam Halgin \& Susan, 2010) berdasarkan perspektif kognitif perilaku, kecemasan menyeluruh merupakan akibat adanya distorsi kognitif yang dapat terlihat dari proses saat individu mengkhawatirkan sesuatu. Secara teoritis, kecemasan muncul diawali dari adanya stimulus dari luar yang berupa kondisi yang menekan bagi anak, yang kemudian dipersepsi oleh anak menggunakan sistem kognitifnya. Pengetahuan tersebut dapat terbentuk dari keyakinan pendapat orang lain, maupun pendapat individu sendiri serta dunia luar. Menurut Burns, distorsi kognitif ini dipengaruhi oleh pengetahuan yang terbatas yang dimiliki oleh anak, sehingga reaksi yang digunakan untuk mengatasi rasa cemasnya menjadi tidak efektif, sehingga kecemasan tidak berkurang dan terus berkelanjutan (Safaria \& Saputra, 2009).

Kecemasan yang dialami anak pada umumnya dikarenakan adanya perubahan dalam hidupnya atau adanya tekanan yang berlebih, misalnya memasuki sekolah yang baru, target dan tuntutan sekolah, beban tugas sekolah yang padat, serta adanya perasaan malu terhadap lingkungan sosialnya atau penampilan yang buruk, baik penampilan fisik ataupun yang berkaitan dengan prestasi (Safaria \& Saputra, 2009). Dinamika kecemasan pada anak dengan taraf intelektual borderline juga sama. Ketika anak bertemu dengan situasi yang menekan, di dalam pikiran anak juga terjadi proses kognitif. Hanya saja, dengan keterbatasan intelektualnya, maka pengetahuan dan strategi pemecahan masalah anak pun terbatas dalam memproses stimulus tadi, sehingga akan terjadi bias kognitif dalam pikirannya (distorsi kognitif). Selanjutnya, ketika strategi pemecahan masalah gagal dilakukan oleh anak, dan yang akan muncul adalah reaksi kecemasan. Ketika problem solving itu tidak mampu mereduksi kecemasan anak, maka kecemasan tersebut akan semakin naik intensitasnya.

Kondisi yang memungkinkan menekan bagi anak dengan kapasitas intelektual borderline adalah adanya tuntutan pendidikan sekolah formal. Beban tugas dan tuntutan akademik dari sekolah yang wujudnya adalah ketuntasan akademik menjadi tekanan tersendiri bagi anak dengan keterbatasan intelektual (Yehuda, 2007). Anak dengan taraf intelektual borderline akan memproses tekanan tersebut, dengan sistem kognitifnya, yang kemudian dengan terbatasnya pengetahuan dan 
strategi pemecahan masalah yang dimilikinya, maka akan muncul penilaian irasional sebagai reaksi kecemasan terhadap kesuksesan dan kemampuan mereka guna mendapatkan pengakuan dari orang lain (Havard Medical Letter, 2003), dimana kecemasan tersebut muncul karena adanya perasaan ketakutan yang cukup mendalam, ketakutan akan gagal, ditolak, dan diejek oleh lingkungannya. Hal di atas menggambarkan bahwa seorang anak dengan taraf intelektual borderline rentan akan mengalami gejala gangguan kecemasan. Hal ini tidak bisa dipandang sebelah mata dan membutuhkan penanganan khusus dan segera. Menurut Podell, Martin, \& Kendall (2009) gangguan kecemasan tidak akan berkurang dengan bertambahnya usia dan jika tidak ditangani dengan baik maka akan dibawa pada usia dewasa. Gangguan ini terkait dengan kesulitan dalam prestasi akademik, hubungan sosial dan teman sebaya, dan kesehatan emosional.

Reaksi kecemasan sendiri muncul dalam tiga reaksi, antara lain reaksi kognitif, afeksi, dan fisiologis. Calhoun dan Acocella (dalam Safaria \& Saputra, 2009) menyampaikan ada tiga reaksi kecemasan, yaitu sebagai berikut :

a. Reaksi emosional, yaitu yang berkaitan dengan persepsi individu terhadap pengaruh psikologis dari kecemasan yang juga bisa muncul melalui perilaku misalnya akibat ketegangan, sedih, perasaan inferior/tidak mampu, serta menjelekan diri sendiri.

b. Reaksi kognitif, yaitu ketakutan dan kekhawatiran yang berpengaruh terhadap kemampuan berpikir jernih sehingga menganggu kemampuan memecahkan masalah dan mengatasi tuntutan lingkungan.

c. Reaksi fisiologis, yaitu reaksi yang ditampilkan tubuh terhadap sumber ketakutan dan kekhawatiran. Reaksi ini berkaitan dengan sistem syaraf yang mengendalikan berbagai otot dan kelenjar tubuh, seperti timbul jantung berdebar, sesak nafas, juga tekanan darah meningkat.

\section{Klasifikasi Borderline}

Taraf kecerdasan borderline sering disebut sebagai kelompok "lambat belajar" di dunia pendidikan. Secara intelektual borderline berbeda dengan retardasi mental, sekalipun keduanya menunjukkan kondisi intelektual di bawah rata-rata. Bordeline tidak termasuk pada kelompok retardasi mental, borderline menjadi kelompok tersendiri yang memisahkan antara retardasi mental dan normal. Apabila merujuk kepada konsep dan definisi retardasi mental perbedaan itu nampak jelas apabila dilihat dari tingkat kecerdasan yang diperoleh berdasarkan skor IQ. Seorang anak dikatakan retardasi mental apabila memiliki skor IQ menyimpang dua standar deviasi (IQ 70 ke bawah), sementara penyimpangan satu standar deviasi (IQ 71 - 85) tergolong anak yang disebut borderline. (Mulyono, 1995).

\section{Karakteristik Boderline}

Perkembangan fungsi intelektual anak dengan taraf kecerdasan borderline yang berada di bawah rata-rata juga dimungkinkan disertai dengan kesulitan dalam perkembangan perilaku adaptif yang akan berakibat langsung kepada kehidupan mereka sehari-hari. Masalah-masalah yang 
dihadapi mereka secara umum meliputi; masalah belajar, masalah penyesuaian diri terhadap lingkungan, serta masalah kepribadian.

\section{Hambatan dalam belajar}

Aktivitas belajar berkaitan langsung dengan kemampuan kecerdasan. Di dalam kegiatan belajar sekurang-kurangnya dibutuhkan kemampuan mengingat dan memahami, serta kemampuan untuk mencari hubungan sebab akibat. Anak-anak yang termasuk dalam kelompok boderline kebanyakan mengalami kesulitan untuk dapat berfikir secara abstrak, belajar apapun harus terkait dengan obyek yang bersifat konkrit. Kondisi seperti itu ada hubungannya dengan kelemahan ingatan jangka pendek, kelemahan dalam bernalar, dan sukar sekali dalam mengembangkan ide (Kephart, 1996). Hasil penelitian Alimin (1997) menunjukkan bahwa anak borderline mengalami cognitive deficite yang tercermin dalam proses kognitif seperti ; persepsi, daya ingat, mengembangkan ide, evaluasi dan penalaran. Pembelajarannya pun diharapkan untuk menghindari penggunaan bahasa yang komplek. Bahasa yang digunakan hendakya berbentuk kalimat tunggal yang pendek dan konkrit sehingga anak mudah untuk memahaminya.

\section{Hambatan dalam Penyesuaian Diri}

Anak borderline juga memiliki karakteristik sulit dalam memahami dan mengartikan norma lingkungan. Hal ini dipengaruhi dari terbatasnya kemampuan anak untuk memahami isyarat social di sekitarnya, juga keterbatasan dalam memandang suatu konsep sebab akibat. (Kephart, 1996).

\section{Hambatan Kepribadian}

Anak borderline cenderung mengalami banyak kegagalan dan frustrasi. Kegagalan lebih dipengaruhi oleh terbatasnya kapasitas intelektual. Akibatnya anak juga memiliki kesulitan dalam memilih problem solving dan labil dalam ketahanan emosinya sehingga menjadi lebih mudah frustrasi. Hal ini berpengaruh negatif terhadap perkembangan kepribadian mereka. Proses kognitif dan proses kepribadian merupakan dua hal yang berdiri sendiri, tetapi keduanya saling mempengaruhi. Proses kognitif terlibat erat dalam perubahan pola kepribadian, dan bahkan dalam reaksi emosi. Sangat masuk akal apabila berpegang pada asumsi dimana orang yang kemampuan mentalnya rendah, kepribadiannya menjadi tidak matang, dan tidak rasional (Kephart, 1996).

Dalam Ingall (1987), kepribadian anak dengan kapasitas kognitif yang rendah juga dapat dianalisa dengan menggunakan teori psikoanalisa Freud, Freud membagi struktur kepribadian ke dalam tiga bagian yaitu; Id, Ego, dan Super Ego. Id merupakan penggerak kepribadian manusia yang bersifat insting dengan prinsif mencari kenikmatan dan menghindari ketidaknyamanan. Ego, yang berfungsi sebagai eksekutif dan bertugas untuk menguji realitas, membawa impuls-impuls dari Id dan membuat keseimbangan antara impuls-impuls yang datang dari Id dengan tuntunan realitas, Ego, merupakan aspek psikologis dari kepribadian. Ego berfungsi sebagai instrumen pelaksana dalam memenuhi kebutuhan Id. Akan tetapi ego tidak dapat memenuhi kebutuhan Id begitu saja, harus memenuhi kaidah normatif dari super ego, sehingga pemenuhan kebutuhan Id tidak bertentangan dengan norma dimana individu berada. Anak-anak yang memiliki kapasitas 
kognitif yang terbatas mengalami kelemahan dalam fungsi ego. Ego yang normal berfungsi untuk menggali dan mempelajari realitas, memahami akibat dari sebuah tindakan, dan belajar untuk menahan keinginan serta yang secara sosial dapat diterima.

Anak borderline mengalami kelemahan dalam proses seperti itu. Kelemahan fungsi ego menyebabkan anak borderline tidak mampu menyalurkan ketegangan insting dalam bentuk perilaku yang dapat diterima. Penyaluran ketegangan dalam mengontrol kecemasan lebih banyak didasarkan pada mekanisme pertahanan diri yang lebih bersifat primitif. Semakin primitif mekanisme pertahanan diri, semakin tidak efektif dalam mereduksi kecemasan. Oleh sebab itu ada kecenderungan anak dengan taraf kecerdasan borderline mempunyai reaksi irasional dan kecemasan yang berlebihan (Kephart, 1996).

\section{METODE}

Penelitian ini menggunakan pendekatan kualitatif. Informan dalam penelitian ini sebanyak 2 orang, dengan menggunakan teknik purposive sampling, yaitu berdasarkan kriteria yang telah ditentukan yaitu : (1) Anak-anak berusia 6 - 12 tahun (2) Memiliki IQ borderline (dibuktikan dengan test inteligensi menggunakan (Weschler Inteligence Scale for Children) (3) terindikasi mengalami gangguan kecemasan akademik, yang diukur menggunakan Children Test Anxiety Scale, Children Test Anxiety Scale dikembangkan khusus untuk anak-anak usia sekolah dan paling banyak digunakan untuk self report untuk mengukur kecemasan situasi di sekolah (Wren \& Beston, 2004). Pengumpulan data dalam penelitian ini menggunakan metode wawancara dan observasi. Wawancara dilakukan pada kedua informan, orang tua dan guru di sekolah. Data observasi didapatkan dari pengamatan di rumah dan di sekolah. Analisa data yang dilakukanmenggunakan prinsip analisa data kualitatif, dalam Creswell (2013) ada 6 tahap analisa data yakni mengolah data, membaca keseluruhan data, mendeskripsikan dan menyajikan kateforisasi dalam bentuk deskripsi dan menginterpretasi.

\section{HASIL DAN PEMBAHASAN}

Kecemasan merupakan hal yang biasa daialami baik oleh orang dewasa maupun anak-anak. Gangguan kecemasan yang terjadi pada anak yang memiliki taraf intelektual borderline merupakan hasil dinamika dari kerentanan kognitif dan kepribadian.

Subyek pertama, subjek adalah anak pertama dari dua bersaudara. Subjek tinggal bersama kedua orang tuanya dan adiknya yang masih bayi. Saat ini subjek duduk di kelas III SD. Selama subjek masih di duduk di TK, subyek cenderung tidak bermasalah. Riwayat kasus subjek dimulai saat subjek duduk di kelas 1 SD. Hal ini dikarenakan di kelas 1, subjek sudah mulai dinilai secara akademik. Dengan demikian, harapan orang tua mulai membebani subjek. Hanya saja, harapan orang tua subyek tidak dapat dipenuhi oleh subyek. Nilai-nilai subjek di sekolah banyak yang berada di bawah rata-rata. Hal ini membuat orang tua subyek bersikap keras pada subjek. Subjek 
sendiri kesulitan dalam akademik, karena secara intelektual subyek berada di taraf intelektual borderline, dengan IQ 72 skala WISC. Terhambatnya beberapa aspek kognitif tadi, menyebabkan subjek kesulitan untuk mengikuti pembelajaran di sekolah. Sehingga anak borderline kesulitan untuk berprestasi seperti anak normal seusianya.

Subyek kedua adalah anak tunggal dari kedua orang tuanya yang sekarang. subyek merupakan anak yang diadopsi orang tuanya sejak usia 3 bulan. Ibu subyek memiliki harapan yang cukup tinggi ke anak tunggalnya ini, supaya anaknya nanti menjadi tulang punggung keluarganya. Ketika ibu angkat, mendapat tawaran untuk mengadopsi subyek, ibu subyek memiliki keinginan untuk mendapatkan pengganti anak kandungnya yang sudah meninggal. Ibu ini berharap subyek dapat menjadi tulang punggung keluarganya ke depannya. Berawal dari harapan tadi, ibu subyek mengatakan bahwa dirinya berharap subyek bisa mendapat nilai yang baik di sekolah.

Kedua subyek mengalami kesulitan dalam akademik, karena secara intelektual keduanya berada di taraf intelektual borderline, dengan subyek pertama IQ 72 dan subyek kedua dengan IQ 70. Menurut Alimin (1997) menunjukkan bahwa anak borderline mengalami cognitive deficite yang tercermin dalam proses kognitif seperti ; persepsi, daya ingat, mengembangkan ide, evaluasi dan penalaran. Hal ini juga dapat dilihat dari gambaran aspek intelektual subyek, dari hasil test WISC (Weschler Inteligence Scale for Children) didapatkan hasil dimana kedua subyek memiliki gambaran intelektual yang hampir sama yakni memiliki kesulitan berpikir secara logis, selain itu klien juga kurang dalam hal konsentrasi. Terbatasnya dalam hal konsentrasi menyebabkan subyek rentan stres jika harus menghadapi tugas dengan aktivitas mental yang lama. Terhambatnya beberapa aspek kognitif tadi, menyebabkan subyek kesulitan untuk mengikuti pembelajaran di sekolah. Sehingga anak borderline kesulitan untuk berprestasi seperti anak normal seusianya.

Ketidakmampuan secara intelektual kedua subyek untuk memenuhi harapan orang tua dan ibu angkatnya, memunculkan perasaan inferior yang pada akhirnya memicu perasaan cemas. Pada kedua subyek, pemicu kecemasan tidak hanya tuntutan dari orang tua, tetapi juga pada tuntutan pencapaian akademik di sekolah. Apalagi karakteristik kepribadian subyek dengan intelektual borderline juga rentan terhadap stress dan frustasi. Hal ini didukung oleh pendapat Kephart (1996) yang menyatakan bahwa terbatasnya kapasitas intelektual berpengaruh pada ketahanan emosinya, sehingga menjadin lebih mudah emosi. Meskipun proses kognitif dan proses kepribadian merupakan dua hal yang berdiri sendiri, tetapi keduanya saling mempengaruhi. Asumsinya pada anak dengan kapasitas intelektual yang terbatas maka kepribadiannya menjadi tidak matang dan tidak rasional. Sementara sesuai dengan pandangan Freud (dalam Feist, Feist\&Roberts, 2017) m enyatakan bahwa anak-anak yang memiliki kapasitas kognitif yang terbatas mengalami kelemahan dalam fungsi ego. Ego yang normal berfungsi untuk menggali dan mempelajari realitas, memahami akibat dari sebuah tindakan, dan belajar untuk menahan keinginan serta yang secara sosial dapat diterima. Anak borderline mengalami kelemahan dalam proses seperti itu. Kelemahan fungsi ego menyebabkan anak borderline tidak mampu menyalurkan ketegangan insting dalam bentuk 
perilaku yang dapat diterima. Penyaluran ketegangan dalam mengontrol kecemasan lebih banyak didasarkan pada mekanisme pertahanan diri yang lebih bersifat primitif. Semakin primitif mekanisme pertahanan diri, semakin tidak efektif dalam mereduksi kecemasan. Oleh sebab itu ada kecenderungan anak dengan taraf kecerdasan borderline mempunyai reaksi irasional dan kecemasan yang berlebihan (Kephart, 1996).

Kapasitas intelektual yang terbatas, menyebabkan subjek tidak memiliki banyak pilihan problem solving untuk mengatasi masalah dan kecemasan yang dihadapinya. Sehingga yang terjadi adalah reaksi kecemasan. Pada awal riwayat kasus di kelas 1 SD, subjek pertama mencoba mereduksi kecemasannya dengan menarik diri dari lingkungannya. Subjek cenderung menghindari subyek-subyek yang membuatnya cemas, seperti teman-teman dan gurunya. Subjek selalu merasa bahwa semua temannya pintar dan dia tidak. Subjek takut suara keras guru, sehingga membuatnya berpikir bahwa ia sedang dimarahi dan apa yang ia kerjakan salah Oleh karena itu, subjek memilih untuk tidak menjawab pertanyaan guru ataupun bertanya di dalam kelas.

Subyek kedua diawal ia mencoba mereduksi kecemasannya dengan memilih diam ketika di sekolah, terutama ketika diberi pertanyaan atau mengerjakan test. Mekanisme pertahanan diri klien yang primitif ini, tidak efektif mengatasi kecemasan klien. Hal tersebut menyebabkan ketegangan dan kecemasan klien pun tidak berkurang. Perilaku itu kemudian berkembang menjadi teriak-teriak dan tidak dapat dikendalikan ketika subyek mengalami kecemasan yang sangat. Pola perilaku ini kemudian diperkuat oleh tanggapan lingkungan yang sangat terfokus pada subyek. Selain itu subyek juga mandapatkan dispensasi ketika subyek mulai menunjukan perilaku teriak-teriak dan memukul-mukul mejanya. Subyek merasa bisa lepas dari kecemasannya karena subyek juga lepas dari tugas yang membuatnya tertekan, selain itu subyek juga mendapatkan perhatian dari lingkungan di sekitarnya, misalnya saja subyek akhirnya didampingi saat mengerjakan tugastugasnya.

Berbeda dengan subjek pertama, perilakunya yang cenderung diam dan menghindari hal-hal yang membuatnya cemas, juga tidak menyelesaikan rasa cemasnya. Subjek menjadi menarik diri dari orang-orang yang dia anggap membuatnya takut. Menurut guru subjek, subjek juga cenderung tidak berani berkonflik dengan teman. Subjek memilih untuk menangis ketika diganggu oleh temannya. Sikap dengan guru pun demikian, ketika ditanya, tidak berani menjawab, bahkan menatap mata pun tidak berani, apalagi kalau dipaksa untuk menjawab, subjek langsung menangis. Secara akademik, nilai subjek memang di bawah rata-rata. Guru kelasnya mengatakan karena tidak berani bertanya maupun aktif di kelas, subjek tidak pernah mendapat nilai tambahan untuk membantu nilai-nilainya.

Ketika ditanyakan pada subjek, subjek mengaku tidak bisa berpikir ketika ditanya, karena takut jawabannya sehingga ia akan dimarahi guru dan ditertawakan oleh teman-temannya. Subjek merasa bahwa teman-teman lebih pintar dari dirinya. Subjek juga mengatakan bahwa dirinya susah 
tidur ketika akan ada ulangan atau latihan soal di sekolah, subjek takut jika ia tidur maka apa yang ia pelajari akan hilang saat ia tidur.

Pada subyek kedua, guru di sekolah sudah pernah mencoba mengkomunikasikan hal yang terjadi di sekolah ke orang tua, hanya saja orang tua menanggapinya dengan membawa subyek ke "orang pintar". Di orang pintar ini subyek disebutkan bahwa subyek dirasuki oleh kekuatan gaib. Dengan kartakteristik kognitif subyek yang terbatas, dan fungsi ego yang melemah, maka subyek sulit memahami realitas. Informasi yang diterima subyek diterima dengan mentah. Sehingga subyek meyakini bahwa dirinya benar kerasukan setan.

Semakin tinggi kelas subyek kedua, maka semakin tinggi pula tuntutan baik dari sekolah maupun dari ibu subyek sendiri, sehingga perilaku subyek semakin naik frekuensi dan intensitasnya. Ketika benar-benar cemas dan tegang, subyek kedua sampai kehilangan kesadarannya dan tidak mengenali orang-orang disekitarnya. Hal ini mendapat penguatan dari lingkungan bahwa subyek kedua benar-benar "kerasukan".

Lama kelamaan subyek yang memang pada dasarnya sulit membedakan antara fantasi, harapan, dengan realita, semakin sulit membedakan antara harapannya menjadi penari kubro, fantasinya tentang "kerasukan", dan kecemasan dan ketegangan yang dialaminya. Sehingga sesuai dengan pendapat Wong dan Hakim (2009) yang mengatakan bahwa konflik internal pada diri seseorang, dimana pikiran dan kondisi kejiwaan dalam keadaan labil, tidak tenang dan bermasalah yang belum terselesaikan memicu adanya ledakan emosi (abreaction) sebagai reaksi dari kecemasan klien.

\section{KESIMPULAN}

Dari hasil yang didapat di atas, disimpulkan bahwa kecemasan akademik yang berlebihan yang dialami oleh anak dengan intelektual borderline merupakan hasil dinamika dari kapasitas intelektual yang kurang dan kerentanan kepribadian yang juga menjadi akibat dari kapasitas intelektual yang terbatas. Hal ini sesuai dengan pendapat Kephart (1996) dimana orang yang kemampuan mentalnya rendah, kepribadiannya menjadi tidak matang, dan tidak rasional Pada kedua subjek, Di sekolah, subjek mendapatkan tekanan beban tugas yang padat, juga tuntutan lingkungan mengenai prestasi, hal ini merupakan situasi yang menekan bagi subjek, yang kemudian diproses secara kognitif oleh subjek menggunakan pengalaman dan nilai yang dimiliki anak. Subjek memproses mengalaman tersebut hanya menggunakan pengalaman yang pernah ia alami. Subjek memproses situasi tersebut dengan pengalaman anak, dimana kegagalan dalam prestasi akan dimarahi orang tua dan guru, juga ditertawakan teman-teman. Dari pengalamannya, anak menjadi kesulitan memahami bahwa semua anak juga pernah mengalami pengalaman kegagalan dan keberhasilan. Hal ini yang kemudian menimbulkan perasaan inferior dan muncul kecemasan. Hal tersebut dikarenakan problem solving yang dimiliki anak terbatas, maka 
mekanisme pertahanan diri dari kecemannya pun menjadi tidak efektif untuk mereduksi kecemasannya, sehingga kecemasannya semakin kuat.

\section{Saran}

Berdasarkan hasil penelitian yang sudah dilakukan maka saran yang dapat diberikan adalah:

1. Bagi orang tua, agar memahami kelebihan dan kelemahan anak. Orang tua diharapkan mampu mengapresiasi kelebihan anak yang lain, selain aspek akademis. Misalnya memuji ketika anak rajin belajar, rajin membantu orang tua, sehingga anak melihat dan merasakan respon positif terhadap dirinya. Hal ini didasarkan pada anak dengan intelektual borderline akan lebih menangkap hal-hal yang real. Selain itu juga tidak memberikan tuntutan yang tinggi terhadap pencapaian prestasi akademis anak. Hal ini dimaksudkan agar memberikan lingkungan yang kondusif bagi anak sehingga meminimalkan munculnya kecemasan.

2. Bagi guru di sekolah, diharapkan mampu memahami diferensiasi setiap anak didiknya, sehingga bisa memberikan perlakuan yang tepat sesuai dengan kapasitasnya masingmasing. Apresiasi terhadap hal-hal di luar aspek akademis juga perlu dilakukan, misalnya kesopanan, kerajinan anak.

3. Bagi peneliti selanjutnya, hasil penelitian ini dapat dimanfaatkan sebagai tambahan informasi pada penelitian dengan topik serupa. Hal yang perlu dipertimbangkan dalam proses penelitian adalah respon kecemasan yang mungkin muncul ketika proses penelitian, peneliti diharapkan mampu mengantisipasi, misalnya dengan memberikan relaksasi. Selain itu, penelitian ini bisa menjadi penelitian pendahuluan untuk mencari teknik intervensi yang tepat untuk mereduksi kecemasan pada anak dengan intelektual borderline.

\section{DAFTAR PUSTAKA}

Creswell, J.W. (2013). Research Design Pendekatan Kualitatif, Kuantitatif, dan Mixed, edisi ketiga. Yogyakarta : Pustaka Pelajar

Feist, Jess., Feist, Gregory J., Roberts, Tomi Ann. (2017). Teori Kepribadian Buku 1 Edisi 8. Jakarta: Salemba Humanika.

Gosch, EA., Flannery-Schroeder, E., Mauro, CF., \& Compton, SN. (2006). Priciples of Cognitive Behavioral Therapy for Anxiety Disorders in Children. Journal of Cognitive Psychotherapy, $20,247-262$

Halgin, R.P., \& Susan, K.W. (2010). Psikologi Abnormal: Perspektif Klinis pada Gangguan Psikologis. Edisi 6. Alih Bahasa: Aliya Tusya'ni, dkk. Jakarta : Penerbit Salemba Humanika.

Havard Medical Letter Vol 21 Children Fears and Anxieties. (2003). Boston: Havard Medical School.

Kephart, Newell.C. 1996. Perceptual Training In The Curriculum. Merrill: Publishing Company.

Nevid, Jeffrey S., dkk. (2005). Psikologi Abnormal edisi kelima Jilid 1. Jakarta: Erlangga. 
Mulyono, Abdulrahman. 1995. Program Pendidikan Individual. Jakarta: Pelatihan Insevise Guru SLB, Depdikbud, Jakarta

Podell, J.L., Martin, E.D., Kendall, P.C.. (2009). Incoporating Play within a Manual-Based Treatment for Children and Adolescents with Anxiety Disorders. New Jersey : John Wiley $\&$ Sons, Inc.

Safaria, Triantoro\&Saputra, Nofrans Eka. (2009). Manajemen Emosi, Sebuah Panduan Cerdas Bagaimana Mengelola Emosi Positif dalam Hidup Anda. Jakarta: Bumi Aksara..

Yehuda, Senecky; Inbar, Dov; Diamond, Gary; Grossman, Zachi; Apter Allan; Kahan, Ernesto. (2007). Pediatricians Satisfication with their Abilities to Care for Children with Developmental, Behavioral, and Psychosocial Problems. Pediatrics Informational Vol 49.

Wenar \& Kerig. 2005. Developmental Psychopathology. 5th ed. Mc Graw Hill

Wong, W\&Hakim, Andri. 2009. Dahsyatnya Hypnosis. Jakarta: Visimedia.

Zaenal Alimin. 1997. Aplikasi Teori Perkembangan Kognitif Piaget Dalam Pembelajaran Anak Tunagrahita. Bandung: PLB FIP. 